\title{
Ecological restoration by soil transfer: impacts on restored soil profiles and topsoil functions
}

\author{
Adeline Bulot ${ }^{1,2,3}$, Kevin Potard $^{4}$, Fabrice Bureau $^{4}$, Annette Bérard $^{5}$, Thierry Dutoit ${ }^{1}$
}

\begin{abstract}
A last resort means to restoring a severely degraded ecosystem can involve soil transfer, especially when destruction of an undegraded system has been previously independently planned. We measured the impact of different soil transfer treatments that varied in vertical and orderly reconstitution of the main soil horizons on the microbial activity and organic matter composition during restoration of a Haplic Cambisol in a steppe ecosystem. There were differences between the topsoil of the reference ecosystem and the soil transfer treatments in terms of physicochemical parameters and microbial activity, but this was not the case when topsoil was not replaced at the soil surface. Three years following restoration, the transferred topsoil treatment, where the three main soil layers were transferred, contained lower particulate organic matter content than the steppe reference soil, despite similarity in potential carbon mineralization. Soil profile descriptions revealed strong differences in overall organization between the transferred soil and the undisturbed steppe soil, particularly with respect to lower biological activity and a lack of connectivity between pedological horizons via the plant root systems and the earthworm activity in the transferred soil. This suggests that soil transfer conducted to retain soil horizons provides good results when the topsoil is transferred, but it may result in altered biological activity, profile morphology, and organic matter content compared with the reference system.
\end{abstract}

Key words: Mediterranean dry grassland, microbial biomass, particulate organic matter, physicochemical properties, soil profile, soil reconstruction

\section{Implications for Practice}

- Soil transfer without stock piling can improve physicochemical and microbial properties and processes of a Haplic Cambisol topsoil in the short term.

- Retaining the soil vertical organization is the best way to restore topsoil physicochemical parameters and microbial activity.

- The lack of exchanges (water, roots, and earthworms) observed in the short term between the different soil layers may affect the future recovery of the whole soil trench and its associated aboveground vegetation.

- This methodology of soil transfer can be used as a last resort in the ecological restoration of extremely disturbed environments when the destruction of the soil of the donor site has been planned independently before the restoration operation.

\section{Introduction}

To restore ecosystems, it is important to take into account both vegetation and soil (Heneghan et al. 2008). As an example, restoring adequate fertility to that of the reference ecosystem may be prerequisite for reestablishment of a desired species-rich plant community (Janssens et al. 1998; Jaunatre et al. 2014). During a soil transfer, soil material and biota are translocated from a donor site to a receiver site, which ensures the transfer of soil physicochemical attributes, soil organic matter, pedofauna, soil flora, and microbial biomass (Clewell \& Aronson 2013). However, soil transfer can have negative impacts on plant communities, leading for example to colonization by nontarget species such as ruderal or invasive species. These nontarget species are often promoted by the release of nitrate from the accelerated oxidation of organic matter induced by stockpiling before soil transfer (Bruelheide \& Flintrop 2000). The storage and transfer of large quantities of soil therefore have also an impact on its properties, its quality, and the life it supports (Johnson et al. 1991; Whalley et al. 1995; Curry 2004). Moreover, translocated soil may carry a higher nutrient content due to the disturbance of soil structure (Bruelheide \& Flintrop 2000) and compaction that can occur during transfer (Trueman et al. 2007). Because soil is a vital and a nonrenewable resource

\footnotetext{
Author contributions: TD conceived and designed the research; $\mathrm{ABu}, \mathrm{ABé}, \mathrm{KP}, \mathrm{FB}$, TD performed the experiments; $\mathrm{ABu}, \mathrm{KP}$ analyzed the data; ABé, FB, TD contributed materials/analysis tools; ABu, ABé, FB, TD wrote and edited the manuscript.

${ }^{1}$ Institut Méditerranéen de Biodiversité et d'Ecologie (IMBE), Avignon Université, UMR CNRS IRD Aix Marseille Université, FR ECCOREV, IUT site Agroparc, 337 Chemin des Meinajaries BP 61207, 84911, Avignon cedex 09, France

${ }^{2}$ Agrocampus Ouest, centre d'Angers, Unité Propre Paysage et Ecologie, 2 rue André Le Nôtre, 49045, Angers Cedex 01, France

${ }^{3}$ Address correspondence to A. Bulot, email adeline.bulot@agrocampus-ouest.fr

${ }^{4}$ Fédération de Recherche SCALE-FED 4116, Normandie Université, UR, ECODIV-EA 1293, 76821, Mont Saint Aignan Cedex, France

${ }^{5}$ UMR 1114 EMMAH, UAPV, FR ECCOREV Domaine Saint-Paul, Site Agroparc, 84914, Avignon Cedex 09, France
}

doi: $10.1111 /$ rec.12424 
(Van-Camp et al 2004), soil transfer is not a sustainable restoration process, but direct transfer or hauling may be an alternative in severely degraded ecosystems. Indeed, direct transfer can preserve the properties and soil quality, and it can avoid or minimize seed loss or microbial biomass, from the donor site to the receiver site (Pfannenstiel \& Wendt 1984; DePuit 1984; Nwaishi et al. 2015).

Organic matter dynamics can indicate restoration of soil function in formerly degraded/destroyed ecosystems. Organic matter provides mineral nutrition to plants, aids in circulation and water retention, and creates habitat for soil organisms via soil structure (Stengel et al. 2009). It also contains different pools related to microbial function (e.g. excretion of different amounts and types of enzymes) (Krull et al. 2003; Trumbore 2009), and varies with respect to biological stability (labile, stabile, refractory, and inert), decomposition rate (fast-active, slow-intermediate, and very slow/passive/inert) and turnover time (short, long, and very long). The labile pool (fast-active decomposition rate) reacts quickly (decomposition occurs from days to years) and influences current soil functioning.

A soil transfer was conducted in response to mandated restoration in the La Crau plain (southeastern France steppe) after a pipeline leak (Bulot et al. 2014). Our objective was to assess the degree to which the soil transfer treatments achieved characteristics of a reference soil condition in a short time (3 years). Some pedological parameters (coarse elements, organic stable or passive pools, morphology of soil profile, etc.) can have a slow response to disturbance (Parr \& Papendick 1997). However, other parameters (microbial activity, organic labile pools, etc.) can respond rapidly (DeGryze et al. 2004; Schils et al. 2008). It is then important to measure all these parameters to better estimate the overall soil quality (Haynes 2000; Franzluebbers 2002). We measured the impact of a soil transfer on (1) the morphology of soil profile using descriptors/indicators, (2) organic matter and nutrient dynamics, and (3) microorganisms. Three treatments involving partial or total reconstitution of the soil vertical organization were tested. We hypothesized that only the reconstitution of all pedological horizons would rapidly restore topsoil functioning (microbial biomass and activity, nutrients and organic matter dynamics) and soil profile morphology to represent that of the reference steppe condition.

\section{Methods}

\section{Study Region}

The study was carried out in the La Crau plain, located in the French Mediterranean region, in the foreland of the Western Alps (Fig. 1). This former outlet of the Durance River was generated by quaternary deposits during the Pleistocene (Molliex et al. 2013). The topography is extremely flat, with more than $50 \%$ of the soil surface covered by siliceous stones washed down from the Alps. In this ecosystem, a millennia of interactions among soil, climate, and traditional sheep grazing have shaped a unique steppe plant community in Western Europe (Henry et al. 2010). A stony conglomerate composed of pebbles contained in a calcium carbonate matrix prevents the plant root system from reaching the water table located 40-60 cm deep (Römermann et al. 2005). The climate is Mediterranean, with a mean annual temperature of $14.5^{\circ} \mathrm{C}$, an average $540 \mathrm{~mm}$ yearly precipitation, mainly in spring and autumn, and 110 days/year with a wind more than $50 \mathrm{~km} /$ hour (Devaux et al. 1983).

The soil is a shallow Mediterranean red soil with a soil surface layer removed by wind erosion during the Late Glacial Period. This soil is called "fersialsol leptique" according to the "Référentiel Pédologique 2008" (AFES 2009), corresponding to "Haplic Cambisol" in WRB (2006). The soil consists of three pedological horizons (AFES 2009). The first is an organo-mineral topsoil $(0-20 \mathrm{~cm}$ deep) largely composed of rounded pebbles (40-70\% of the surface) from a remnant of the Durance's River former river bed. This horizon contains a mixture of organic $(2.5-3.5 \%)$ and mineral matter. The second is a mineral horizon $(20-40 \mathrm{~cm}$ deep) consisting of brown to red-brown soil that is very stony and differs from the bedrock in a higher degree of alteration (presence of free $\mathrm{Fe}_{2} \mathrm{O}_{3}$ ), and from the surface topsoil in its structure. The last horizon is altered bedrock (more than $40 \mathrm{~cm}$ deep) formed by the dissolution of the matrix hardened by rainwater rendered acidic by moving within the upper horizons.

\section{Study Site}

The study site was an area undergoing ecological restoration as a result of an oil leakage that completely destroyed a 5.5 ha area within the National Nature Reserve $\left(43^{\circ} 31^{\prime} 36.77^{\prime \prime} \mathrm{N}\right.$, $4^{\circ} 53^{\prime} 04.50^{\prime \prime} \mathrm{E}$ ) on 7 August, 2009 (Fig. 1). The whole soil profile, the geological bedrock, and the groundwater were polluted. Restoration consisted in the excavation and removal of the polluted soil $(72,000$ tons) to a specialized treatment centre. Soil was transferred to fill the excavated area. In spring 2011, soil with the same characteristics as the excavated soil was transferred from a nearby active quarry (4 km distance, Fig. 1 ). The soil transfer was done during a rainy period using direct translocation (no stockpiles) with substituting one replaced soil unit for one removed soil unit. The main soil horizons were reconstituted in their different degrees of profile complexity, as derived from the original pedogenesis in the reference undisturbed steppe soil. This process enabled us to evaluate three treatments involving partial or total reconstitution of the soil vertical organization.

\section{Experimental Design}

To assess the importance of soil profile reconstruction for the recovery of soil characteristics, four treatments were applied from January 2011 to April 2011. Five $100 \mathrm{~m}^{2}$ plots of the following vertical organization treatments were established: (1) "topsoil" comprising altered bedrock $(35-40 \mathrm{~cm}$ deep) + subsoil (20-35 cm deep) + topsoil (0-20 cm deep); (2) "subsoil" containing altered bedrock (20-40 cm deep) + subsoil (0-20 cm deep); (3) "altered bedrock" containing only altered bedrock (from surface to $40 \mathrm{~cm}$ deep); and (4) "step," the reference soil transferred from nearby undisturbed steppe with intact 
(A)

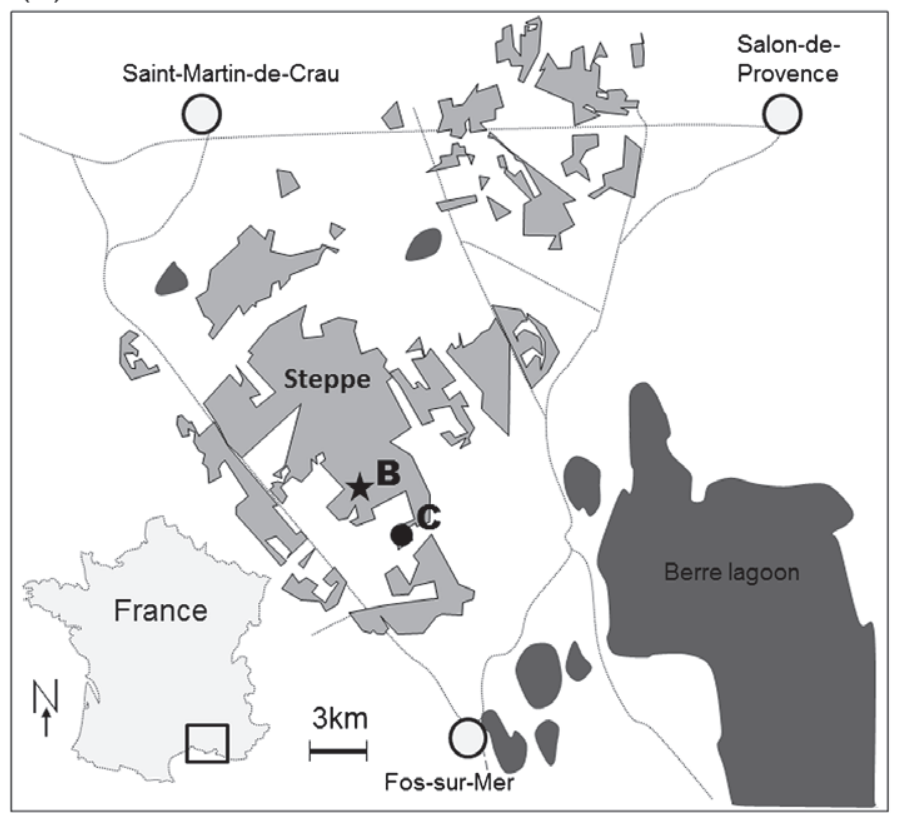

(B)

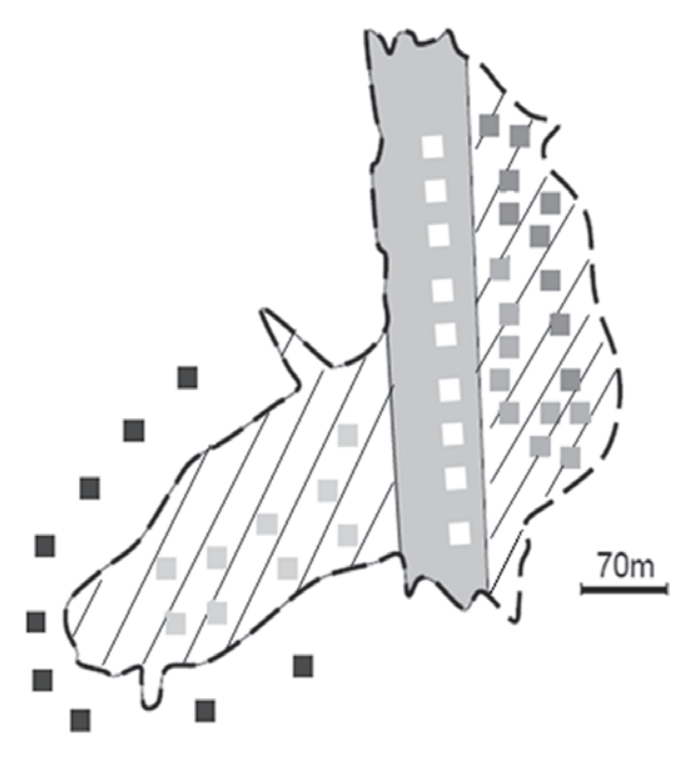

Figure 1. Location of (A) the La Crau plain in France, (B) study site (black star) within the Natural National Reserve (in gray), and (C) the soil donor site (black circle). Schema of the restored site (hatched), zone crossing by oil pipes (gray line), reference steppe (white), and position of quadrats ( $100 \mathrm{~m}^{2}$ ) corresponding to the different treatments (transferred altered bedrock: white; transferred subsoil: light gray; transferred topsoil: gray; reference steppe: very dark gray).

soil vertical organization of altered bedrock, subsoil, and topsoil (Fig. 2). The "step" soil was grazed by sheep. The "altered bedrock" treatment was a negative control because it would have been applied by the industrial owner of the pipeline over the whole area of site if there were no ecological restoration requirements. In winter 2013, 3 years after the soil transfer, soil profile descriptions were realized at the center of one randomly selected plot for each treatment. A profile was dug down to the geological bedrock. The physical and biological states of plots were described according to the standardized method of Baize and Jabiol (2011) (Fig. 2, Table 1).

\section{Soil Analyses}

Soil Sampling. Soil samples were taken and analyzed immediately after the soil transfer in spring 2011 just after the soil transfer (Bulot et al. 2014) and 3 years later in autumn 2013, to evaluate change in $\mathrm{pH}$, nutrients $\left(\mathrm{CaO}, \mathrm{K}_{2} \mathrm{O}\right.$, and $\left.\mathrm{P}_{2} \mathrm{O}_{5}\right)$, and particle sizes (silt, sand, and clay). Five $200 \mathrm{~g}$ soil samples were extracted with a shovel (the soil was too hard with the presence of a lot of pebbles for using a soil core) to at a depth of $10 \mathrm{~cm}$ in the five $100 \mathrm{~m}^{2}$ plots for each treatment. To account for the heterogeneity inside plots, samples were homogenized by mixing three subsamples taken randomly in each plot. The same protocol was used in 2011, 2012, and 2013 to evaluate the particulate organic matter (POM) dynamics and the potential C and net $\mathrm{N}$ mineralization rates.

Physicochemical Parameters. After drying and sieving $(2 \mathrm{~mm})$ the soil, physicochemical properties were measured according to standardized methods: $\mathrm{pH}$ in soil using a water ratio of 1:2.5; $\mathrm{CaO}$ and $\mathrm{K}_{2} \mathrm{O}$ by the Metson method; and available phosphorous by the Olsen method (Olsen 1954; Metson 1957). Percent clay $(<2 \mu \mathrm{m})$, silt $(2-50 \mu \mathrm{m})$, and sand $(50-2000 \mu \mathrm{m})$ were determined according to the Robinson method (Baize 2000) without decarbonation. Total organic $\mathrm{C}$ and total $\mathrm{N}$ content were quantified from bulk soil (before fractionation) in 2011, 2012, and 2013 by dry combustion using a CHN elemental analyzer in the laboratory of soil analyses of Arras (ISO 10694).

Physical Fractionation of Soil Organic Matter. Physical fractionation of soil organic matter allows labile pools to be distinguished from stable pools (Feller 1979). POM is biologically and chemically active and is part of the labile (easily decomposable) pool of soil organic matter (Cambardella \& Elliott 1992; Carter et al. 2003) characterized by decaying plant residues ranging in size from 50 to $2,000 \mu \mathrm{m}$. This organic matter pool was determined from air-dried soil samples which were sieved to $2 \mathrm{~mm}$. We used a simplified NF X31-516 method (2007) for the granulodensimetric fractionation of soil POM in water. This method revealed the quality of the organic reserves in the soil (labile pools ranging from 50 to $2,000 \mu \mathrm{m}$ and stable pools $<50 \mu \mathrm{m}$ ). We have also measured the POM ratio relative to the total soil mass (POM weight \%), ratio of POM C to total organic carbon (C-POM/organic $\mathrm{C}$ ), and ratio of total organic carbon to total nitrogen $(\mathrm{C}: \mathrm{N})$.

Labile Pools of $\mathbf{C}$ and $\mathbf{N}$. Labile organic matter pools were estimated by measuring potential $\mathrm{C}$ and net $\mathrm{N}$ mineralization 


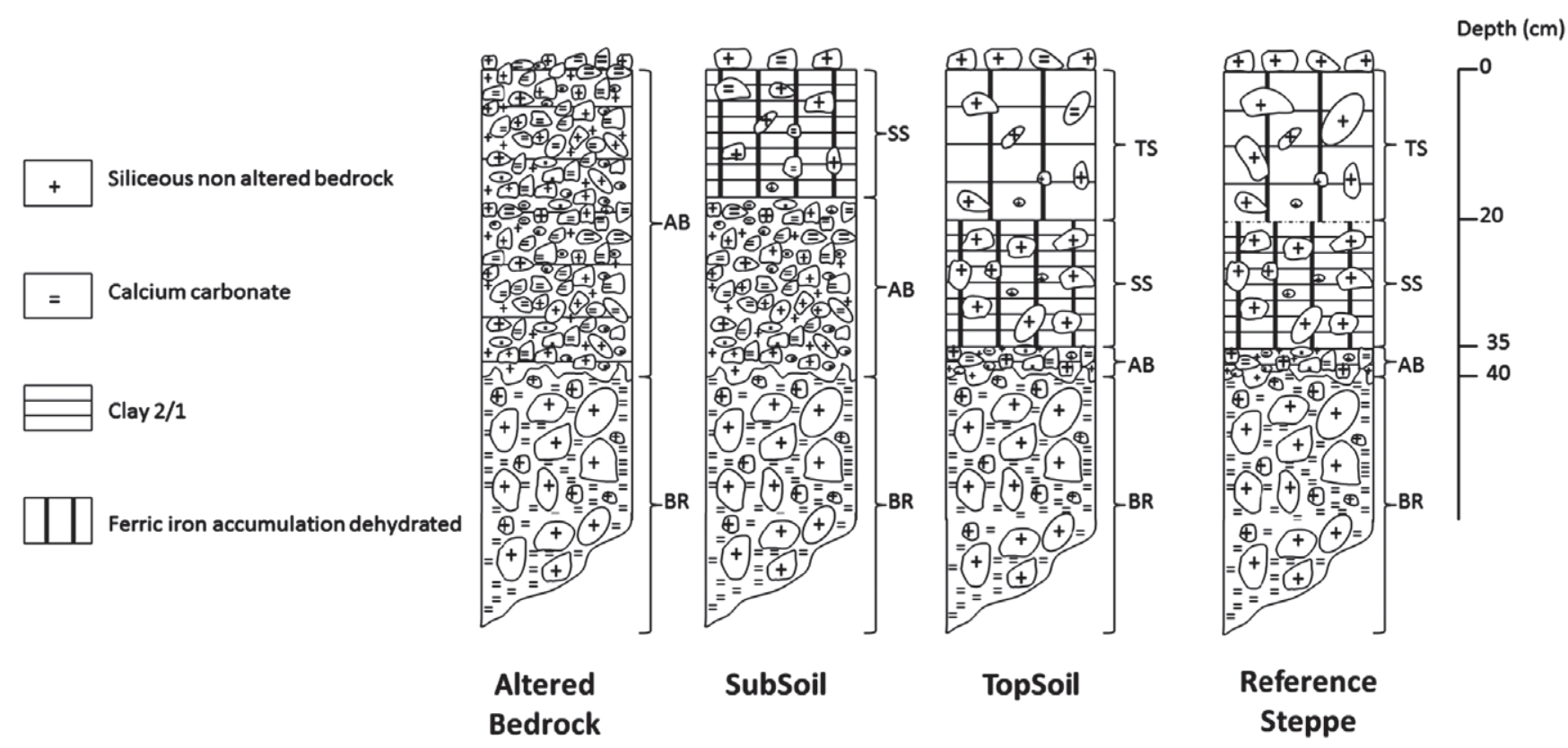

Figure 2. Soil pedological profiles realized in autumn 2013. Soil profiles were measured in each treatment: reference steppe (Step.), transferred topsoil (TS), transferred subsoil (SS), and transferred altered bedrock (AB).

rates using aerobic incubations under standard laboratory conditions $\left(80 \%\right.$ water holding capacity, $28^{\circ} \mathrm{C}$ ) for 28 days (Hart et al. 1994; Robertson et al. 1999). The indicators of potential C mineralization were (1) the quantity of $\mathrm{C}$ mineralized as $\mathrm{CO}_{2}-\mathrm{C}$ during 28 days ( $\mathrm{mg} \mathrm{CO} 2-\mathrm{C} \mathrm{g}$ dry soil ${ }^{-1} 28 \mathrm{~d}^{-1}$ ) and (2) the $\mathrm{C}$ mineralization rate calculated from the ratio of $\mathrm{C}$ mineralized as $\mathrm{CO}_{2}-\mathrm{C}$ during 28 days and total organic $\mathrm{C}$ in the bulk soil.

Microbial Metabolic Diversity. In 2013, soil respiration and microbial metabolic diversity were measured. We used the microrespirometry method, which measures substrate-induced respiration (SIR) response of the whole-soil samples in a short-term bioassay (Chapman et al. 2007).

Quantification of $\mathrm{CO}_{2}$, a by-product of mineralization by microorganisms, was used to assess aerobic soil respiration. The $\mathrm{CO}_{2}$ emission rate was quantified via microrespiration using the MicroResp ${ }^{\mathrm{TM}}$ system (Campbell et al. 2003). A 96-well microplate $(1.2 \mathrm{~mL}$ volume) was filled with soil (fresh soil, sieved to $2 \mathrm{~mm}$ ). Wells received either water alone (basal respiration $[\mathrm{BR}]$ ) or aqueous carbon substrates (SIR). The microplate was then sealed to a colorimetric $\mathrm{CO}_{2}$-trap microplate and incubated in the dark at $23 \pm 2^{\circ} \mathrm{C}$ for 6 hours. Absorbance of the detection microplate was measured at $570 \mathrm{~nm}$. The quantities of $\mathrm{CO}_{2}$ released were calculated with a calibration model (Renault et al. 2013) and results were expressed in $\mu \mathrm{g} \mathrm{C}-\mathrm{CO}_{2} \mathrm{~g}^{-1}$ hour ${ }^{-1}$. Mineralization of seven carbon substrates (glucose, trehalose, D-cellobiose, glycine, L-alanine, D-(+)-glucosamine, and malic acid) was used to quantify community-level physiological profile (CLPP). The added carbon substrates were chosen to represent root exudates, and other organic matter inputs of plant or animal origin. This enabled us to assess the catabolic diversity of the soil and microbial biomass via measurements SIR glucose
(Anderson \& Domsch 1978). The metabolic quotient $\mathrm{qCO}_{2}$ was calculated as the ratio of BR to SIR glucose (Chapman et al. 2007; Bérard et al. 2011) to determine how efficiently microorganisms use available carbon in soil (Anderson \& Domsch 1990). This quotient is considered a microbial eco-physiological indicator.

\section{Statistical Analysis}

To analyze data on physicochemical parameters, organic matter, microbial metabolic diversity, and microbial activity, one-way analysis of variance (ANOVA) tests were performed, followed by post hoc Tukey's tests. These tests were performed to compare means $(\alpha=0.05)$ between the different modalities of soil transfer during the last year of monitoring (2013). When data did not conform to parametric conditions, means normality of model residuals (Shapiro's tests) and homogeneity of variances (Mauchly's tests), treatments were compared via nonparametric tests: Kruskal-Wallis tests, followed by pairwise Mann-Whitney-Wilcoxon comparisons with a $p$-value adjustment according to Benjamini-Hochberg's method (Benjamini \& Hochberg 1995).

Organic matter (POM and C-POM/organic C) did conform to the normality of model residuals (Shapiro's tests) and the homogeneity of variances (Mauchly's tests), so repeated measures ANOVAs were performed followed by pairwise $t$-tests with a $p$-value adjustment according to Benjamini and Hochberg (1995) to compare means among 3 years of monitoring $(2011,2012$, and 2013) within each treatment. We used paired $t$-test with also a $p$-value adjustment according to Benjamini-Hochberg's method (Benjamini \& Hochberg 1995) to compare two monitoring years (2011 and 2013) for 


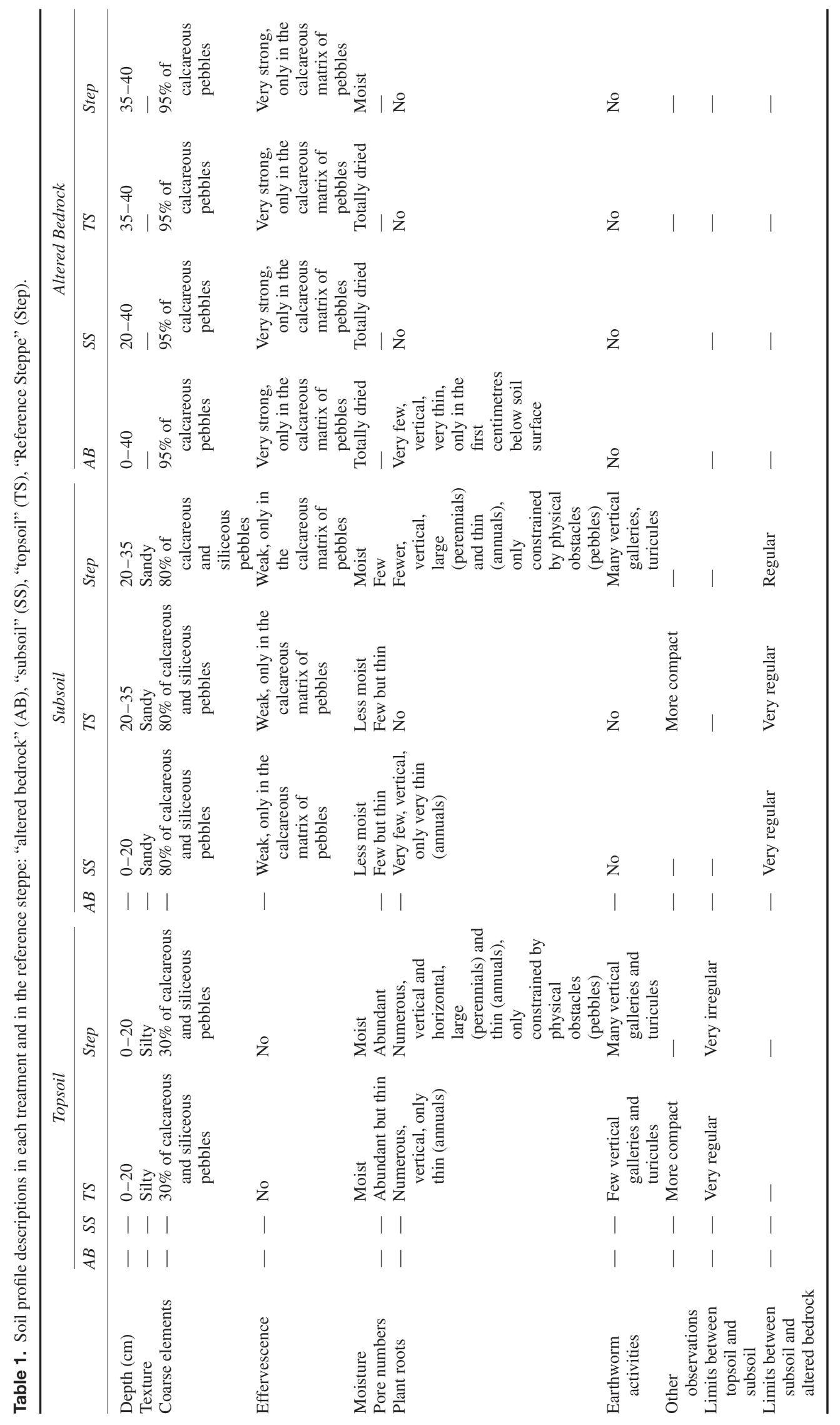


Table 2. Physicochemical qualities (autumn 2013) of four treatments realized in a restoration soil transfer experiment at depth of $10 \mathrm{~cm}$ in the five $100 \mathrm{~m}^{2}$ plots (La Crau, southeastern France). The measured values are means \pm standard errors; $F, \chi^{2}$, and $p$ correspond to the $F$ value, the $\chi^{2}$ value, and the $p$ value resulting from ANOVA tests or Kruskal-Wallis (degrees of freedom $=3.00$ in all cases). Within a row, two cases with a different letter have significantly different values according to Tukey post hoc tests or Mann-Whitney-Wilcoxon tests.

\begin{tabular}{|c|c|c|c|c|c|}
\hline & $\begin{array}{c}\text { ANOVA/Kruskal- } \\
\text { Wallis }\end{array}$ & Transferred Altered Bedrock & Transferred Subsoil & Transferred Topsoil & Topsoil of Reference Steppe \\
\hline Silts $(g / k g)$ & $\begin{array}{l}F=299.9 \\
p<0.001\end{array}$ & $177.6 \pm 1.68^{\mathrm{d}}$ & $317.8 \pm 3.84^{\mathrm{c}}$ & $340.2 \pm 1.06^{\mathrm{b}}$ & $371.2 \pm 2.38^{\mathrm{a}}$ \\
\hline Sands $(\mathrm{g} / \mathrm{kg})$ & $\begin{array}{l}F=204.1 \\
p<0.001\end{array}$ & $742.2 \pm 2.77^{b}$ & $463.8 \pm 4.98^{c}$ & $413.0 \pm 3.81^{\mathrm{d}}$ & $772.8 \pm 180.40^{\mathrm{a}}$ \\
\hline Clays $(\mathrm{g} / \mathrm{kg})$ & $\begin{array}{l}F=299.9 \\
p<0.001\end{array}$ & $80.2 \pm 1.22^{\mathrm{c}}$ & $218.4 \pm 3.65^{b}$ & $246.8 \pm 3.21^{\mathrm{a}}$ & $216.0 \pm 1.52^{b}$ \\
\hline Organic carbon (g/kg) & $\begin{array}{l}F=185.7 \\
p<0.001\end{array}$ & $2.412 \pm 0.18^{\mathrm{d}}$ & $9.238 \pm 0.19^{c}$ & $14.360 \pm 0.27^{b}$ & $18.700 \pm 0.35^{\mathrm{a}}$ \\
\hline Total nitrogen $(\mathrm{g} / \mathrm{kg})$ & $\begin{array}{l}F=323.6 \\
p<0.001\end{array}$ & $0.1374 \pm 0.004^{\mathrm{d}}$ & $0.9062 \pm 0.018^{c}$ & $1.3460 \pm 0.016^{\mathrm{b}}$ & $1.5340 \pm 0.024^{\mathrm{a}}$ \\
\hline $\mathrm{P}_{2} \mathrm{O}_{5}(\mathrm{~g} / \mathrm{kg})$ & $\begin{array}{l}F=3.1 \\
p>0.05\end{array}$ & $0.0100 \pm 0.0000$ & $0.0076 \pm 0.0005$ & $0.0080 \pm 0.0002$ & $0.0084 \pm 0.0002$ \\
\hline
\end{tabular}

$\mathrm{C}$ biodegradation and net $\mathrm{N}$ mineralization. All statistical analyses were performed with $\mathrm{R}$ software version 2.15.2. (The R Foundation for Statistical Computing 2012), using its native packages for univariate analyses and additional packages ade4 (Chessel et al. 2004; Dray \& Dufour 2007) and car (Fox \& Weisberg 2011).

\section{RESULTS}

Three years after the soil transfer, there were significant differences in soil physical characteristics among the soil transfer and the "step" treatment (Table 2). Silt content increased with vertical organization and depth to bedrock from the negative control to the "step" treatment. Conversely, sand content decreased from the negative control to the treatment "topsoil." With respect to clay content, there were no significant differences among the "subsoil" and "step" treatment. There was significantly higher clay content in the "subsoil" treatment, but lower clay content in the negative control. Organic $\mathrm{C}$, total $\mathrm{N}$, and $\mathrm{K}_{2} \mathrm{O}$ content increased with vertical organization and depth to bedrock from the negative control to the "step" treatment, with no significant difference found for $\mathrm{K}_{2} \mathrm{O}$ between the "topsoil" treatment and the "step" treatment (Table 2). Conversely, $\mathrm{pH}$ decreased from the negative control to the treatment "step." In addition, $\mathrm{CaO}$ was significantly higher in the negative control and in the treatment "subsoil" than in the treatment "topsoil" and "step." No significant difference was occurred for available phosphorous.

In 2013, POM relative weight (percentage of POM relative to the total soil) differed significantly among treatments $(F=50.17, d f=3, p<0.001$; Fig. 3A). This POM relative weight increased with vertical organization and depth to bedrock from the negative control to the "step." In all treatments the POM relative weight ratio was lower in 2013 as compared with 2011, but this difference was significant only in treatments "topsoil" and "step" treatments (Fig. 3A).

In 2013, the ratio of C-POM/organic C was significantly lower in the negative control than in the other soil transfer treatments and in the treatment "step" $(F=15.42, d f=3, p<0.001$; Fig. 3B). The ratio between organic $\mathrm{C}$ content of POM and total organic $\mathrm{C}$ decreased significantly in the soil transfer between 2012 and 2013, and also in the negative control, dropping to almost $0 \%$, although not significant. In the treatment "subsoil," no significant differences were recorded. In the treatment "topsoil," there was a decreasing trend over the years, with a significantly lower ratio between 2011 and 2013 (Fig. 3B).

The C:N ratio of the bulk soil differed significantly among all treatments. The treatment "subsoil" had the highest value, while the transferred "topsoil" and the treatment "step" had the lowest significant values. The $\mathrm{C}: \mathrm{N}$ ratio in the treatment "step" was significantly higher than in the treatment "topsoil" but significantly lower than in the negative control and in the treatment "subsoil." The C:N ratio of the POM differed significantly between the treatments and the treatment "step," which had the highest value. No significant difference was measured for the $\mathrm{C}: \mathrm{N}$ ratio of the POM fraction $<50 \mu \mathrm{m}$ (Fig. 4).

Potential $\mathrm{C}$ mineralization differed significantly among the treatments, with an increasing gradient from the negative control to the treatment "step" ( $\chi^{2}=16.58, d f=3, p<0.001$; Fig. 5A). However, no significant difference occurred between the "topsoil" and "subsoil" treatments. The only significant C mineralization increase occurred in the treatment "topsoil" and in the treatment "step" between 2012 and 2013 (Fig. 5A). No significant differences were measured among treatments 

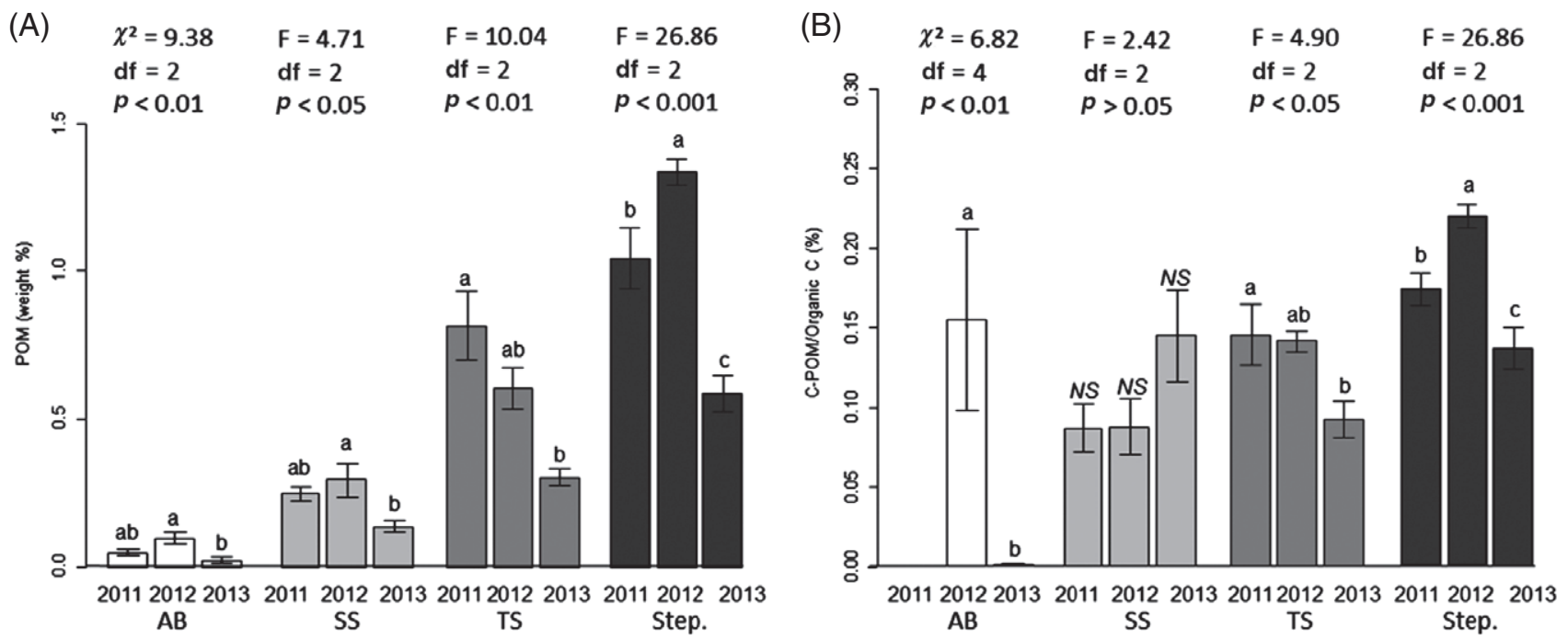

Figure 3. (A) POM (weight \%) between the 3 years of monitoring; (B) C-POM/organic $\mathrm{C}$ (\%) between the 3 years of monitoring measured in each treatment: reference steppe (Step, dark gray), transferred topsoil (TS, gray), transferred subsoil (SS, light gray) and transferred altered bedrock (AB, white). Error bars represent \pm SE, bars sharing common letters or NS do not have significant differences ( $p$-value $>0.05$ ).

$$
\begin{array}{lll}
\chi^{2}=17.60 & \chi^{2}=12.10 & \chi^{2}=7.04 \\
\mathrm{df}=3 & \mathrm{df}=3 & \mathrm{df}=3 \\
p<0.001 & p<0.01 & p>0.05
\end{array}
$$

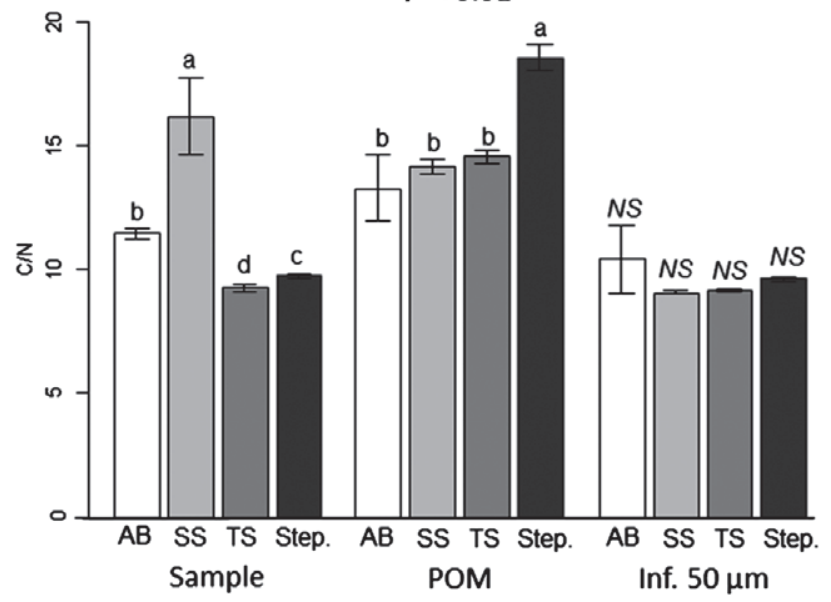

Figure 4. C:N ratio of the bulk soil, the labile POM, and the fraction less than $50 \mu \mathrm{m}$ between the 3 years of monitoring measured in each treatment: reference steppe (Step, dark gray), transferred topsoil (TS, gray), transferred subsoil (SS, light gray) and transferred altered bedrock (AB, white). Error bars represent \pm SE, bars sharing common letters or NS do not have significant differences ( $p$-value $>0.05$ ).

for the ratio between organic $\mathrm{C}$ mineralized in $\mathrm{CO}_{2}$ during short-term incubations and total organic $\mathrm{C}\left(\chi^{2}=4.04, d f=3\right.$, $p>0.05$; Fig. 5B). Between 2012 and 2013, an increasing trend was recorded in all treatments, except in the negative control (Fig. 5B).

Net nitrogen mineralization potential did not differ significantly among treatments, but there was $\mathrm{N}$ immobilization in all treatments except the negative control $(F=3.47, d f=3$, $p>0.05)$. The same trend was measured for the ratio between mineralized nitrogen and total $\mathrm{N}(F=4.44, d f=3, p<0.05)$. Less $\mathrm{N}$ mineralization potential was recorded in all treatments, but these differences were only significant in the negative control between 2012 and 2013 (Fig. 5C). Results were the same for the ratio between mineralized $\mathrm{N}$ and total $\mathrm{N}$, with a significant difference between 2012 and 2013 in the negative control (Fig. 5D).

In 2013, the BR of the treatment "topsoil" was similar to that of the treatment "step," whereas the negative control still showed significantly lower BR than the "topsoil" and "step" treatments (Fig. 6A). The microbial biomass showed the same trend, with significantly higher values in the treatment "topsoil" and in the treatment "step" than in the negative control (Fig. 6B). In contrast, $\mathrm{qCO}_{2}$ values showed an increasing gradient from the treatment "step" to the negative control, with significantly higher values for the negative control than for the "step" treatment (Fig. 6C). Microbial catabolic structure discriminated among the different soil transfer treatments. Very high respiration rates were induced by the malic acid in the treatment "step," and the treatment "topsoil" was the most similar to this one, with a higher catabolism of sugars and malic acid than in the other treatments (Fig. 7).

\section{Discussion}

This study measured the importance of the soil vertical organization to restore a site severely degraded by a petrol leak using soil excavation of and transfer in a Mediterranean dry grassland. The soil horizons were constructed by transferring soil from a donor site which has been destroyed through a quarry extension. Three years after this operation, there was evidence of topsoil recovery. However, the removal of the soil was not the best option to restore and this methodology must be retained as the "last choice" when it is not possible to decontaminate the polluted soil by "in situ" or "ex situ" methodologies. 


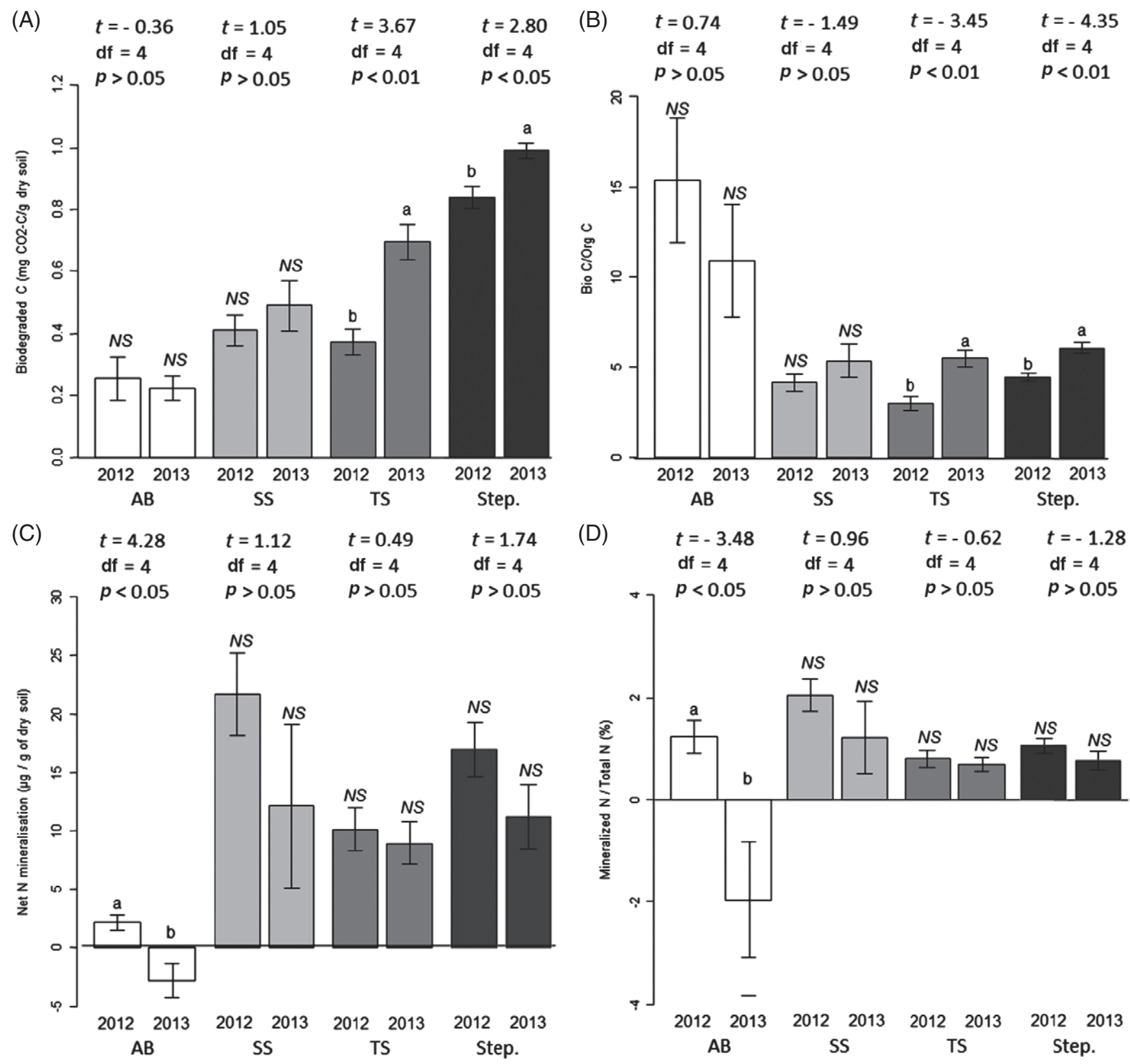

Figure 5. (A) Biodegraded carbon between 2012 and 2013; (B) the ratio between the mineralized carbon in $\mathrm{CO}_{2}$ and the total organic carbon (\%) between 2012 and 2013; (C) net N mineralization (nitrate + ammonium) in controlled conditions during 28 days between 2012 and 2013 ; and the ratio between the mineralized nitrogen (nitrate + ammonium) and the total nitrogen between 2012 and 2013. Means and error standards are given for each treatment: reference steppe (Step, dark gray), transferred topsoil (TS, gray), transferred subsoil (SS, light gray), and transferred altered bedrock (AB, white). Error bars represent $\pm \mathrm{SE}$, bars sharing common letters or NS do not have significant differences ( $p$-value $>0.05$ ).

In comparison with the topsoil of the reference ecosystem, respecting the vertical organization of the three main soil layers during soil transfer was the best method to recover physicochemical parameters and microbiological activity. Nevertheless, three 3 years after the reconstitution of the main soil horizons, some soil characteristics remained different from the reference steppe. Only the transferred "topsoil" was colonized by roots of annual species, with very few earthworm galleries. This could be explained by the destruction of the below- and aboveground biomass of the dominant perennial herbaceous plant species of the steppe vegetation (Brachypodium retusum, Dactylis glomerata) during the transfer (Bulot et al. 2014). Thus, no mixing was apparent between the different soil horizons via the plant root systems or earthworm activities. Accordingly, the limits between the different pedological horizons remained more distinct in the transferred topsoil than in the reference steppe. The soil profile was also drier, particularly with increasing depth. This dryness of the deep soil could result from scarce water 

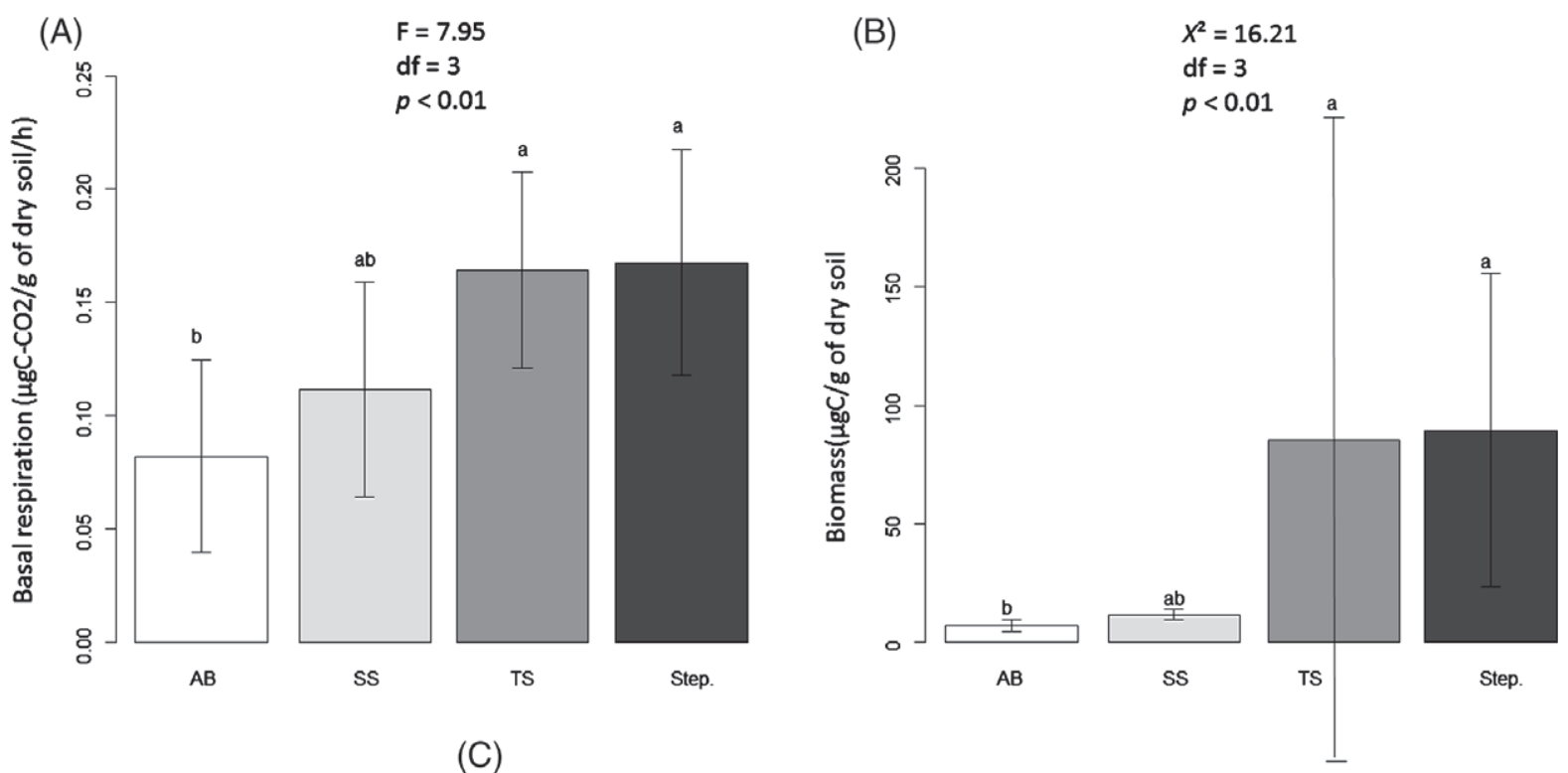

(C)

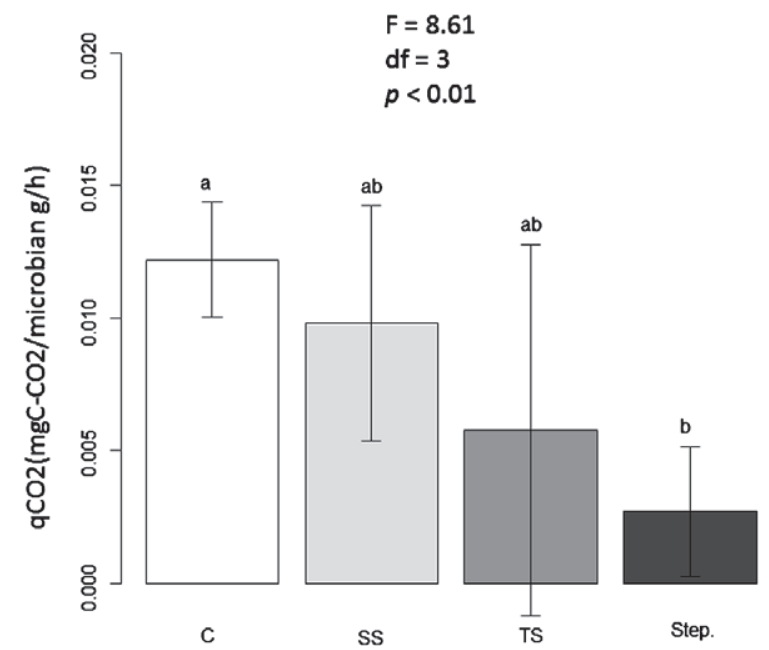

Figure 6. Soil microbial basal respiration (A), microbial biomass (B) and metabolic quotient $\mathrm{qCO}_{2}$ (C) in 2013. Means and error standards are given: reference steppe (Step, dark gray), transferred topsoil (TS, gray), transferred subsoil (SS, light gray), and transferred altered bedrock (AB, white). Error bars represent $\pm \mathrm{SE}$; bars sharing common letters do not have significant differences ( $p$-value $>0.05$ ).

circulation between the soil layers due to the absence of anecic earthworm galleries (Edwards 2002), which were unable to colonize the whole profile likely due to soil compaction. Soil compaction is known to affect the abundance, the biomass, and the distribution of earthworms (Radford et al. 2001). The lack of soil pores also plays a role in the infiltration, storage, and drainage of water (Kutílek et al. 2008). Soil compaction can impact the growth and distribution of roots, thereby affecting water dynamics and plant growth (Unger \& Kaspar 1994). Similar results were observed in the treatments "subsoil" and "altered bedrock," exacerbated by the lack of original topsoil. It is clear that even when the vertical soil organization is fully reconstructed, soil transfer likely disrupt the pedological long-term organization of the whole profile $(0-40 \mathrm{~cm})$. Thus, biological activity, that influences soil structure (earthworm activity and root penetration), the water and air circulation (porosity, permeability), needs to be monitored to evaluate recovery of soil onwards the reference soil profile structure.

With regard to physicochemical parameters, the highest contents of calcium and $\mathrm{pH}$ in the "topsoil" treatment were explained by the solubilization of calcium carbonates from the calcareous matrix or calcareous stones degraded during the transfer. This was especially pronounced in the subsoil and in the altered bedrock, originally closer to the calcareous conglomerate. Similar results were previously obtained in the same area in formerly cultivated fields (Jaunatre et al. 2014) and after trenching for pipelines (Coiffait-Gombault et al. 2012). Increasing organic $\mathrm{C}$ content from the negative control ("altered bedrock") to the treatment "topsoil" supported our expectation that the deeper soil layer would contain less organic matter, and therefore less soil C (AFES 2009). This was also confirmed by the POM content, which accounted for a large part of the 


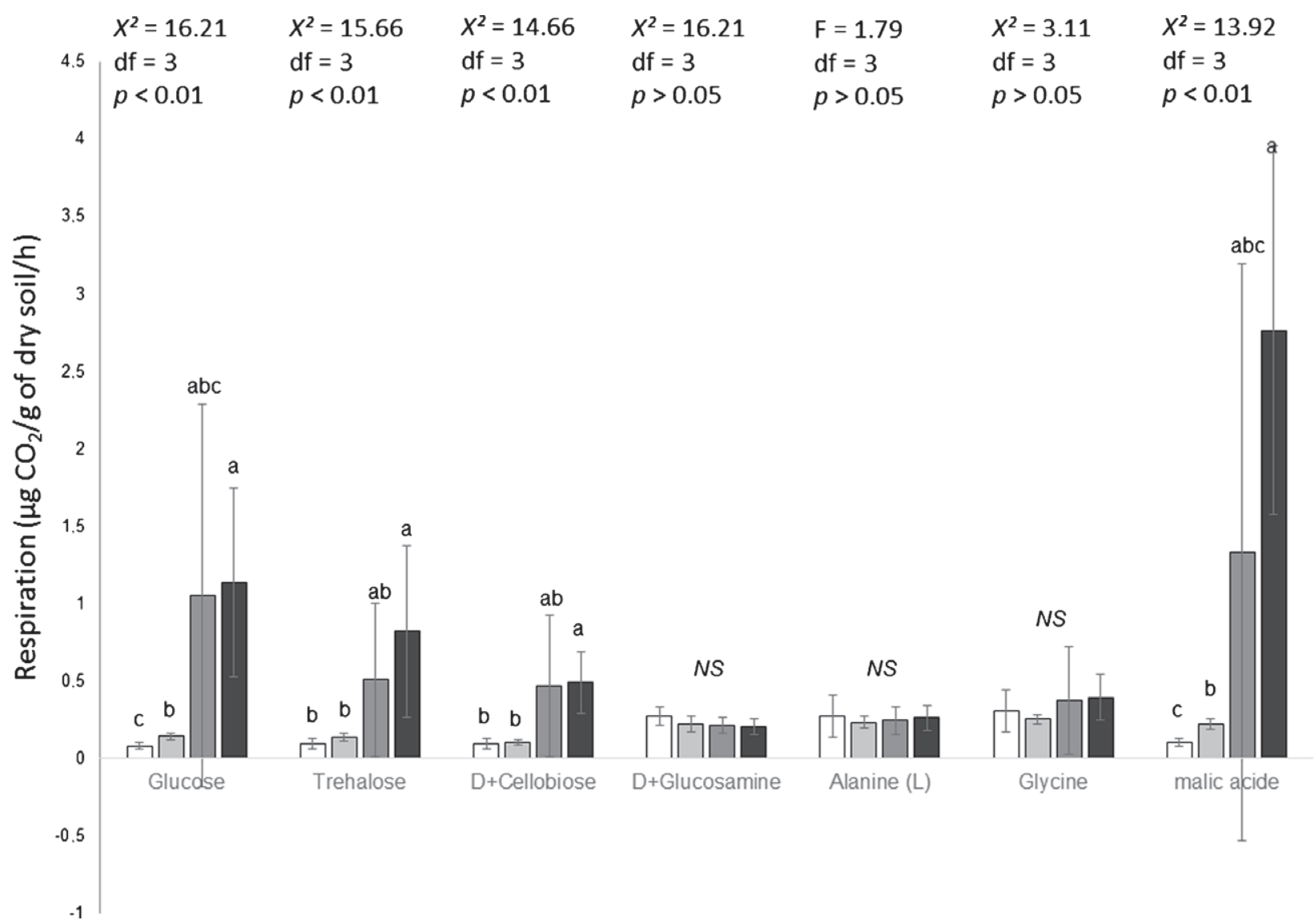

Figure 7. Induced respirations of soil microbial communities. Means and error standards are given: reference steppe (Step, dark gray), transferred topsoil (TS, gray), transferred subsoil (SS, light gray), and transferred altered bedrock (AB, white). Error bars represent $\pm \mathrm{SE}$; bars sharing common letters within a substrate-induced respiration do not have significant differences ( $p$-value $>0.05$ ).

total organic $\mathrm{C}$ content in the different treatments, except for the negative control. However, as with total organic carbon content, POM content was significantly lower in all treatments than in the reference steppe, even in the treatment "topsoil." New easily biodegradable organic matter inputs from annual plants could have boosted the activity of microorganisms, favoring organic matter consumption in this treatment (Fontaine et al. 2003). Significantly higher ratio between particular organic matter ratio and the total soil mass in the reference steppe support this hypothesis. The grazed reference steppe soil may have regularly received new inputs labile organic matter with rapid turnover (Cambardella \& Elliott 1992; Haynes 2000). These contrasts with the treatment "topsoil" which showed a significant decrease in POM after the soil transfer and in the absence of grazing (Bulot et al. 2014). In the reference steppe, temporal variation in POM content over the 3 years of monitoring may have resulted from spatial heterogeneity of the vegetation in the La Crau plain where small patches of perennial species $(B$. retusum), annual species, and bare soil form a complex mosaic (Römermann et al. 2005). Another explanation is that organic matter inputs may vary between years and seasonally within a year as a result of differences in primary production as they are affected by climate, grazing, and plant population dynamics
(Bourrely et al. 1983). In addition, it has been demonstrated that several soil variables show seasonal variations as $\mathrm{N}$ mineralization (Xu et al. 2007; Zhou et al. 2009), and temperature and water soil content are important seasonal factors controlling soil respiration (Bell et al. 2009).

When the $\mathrm{C}$ content of $\mathrm{POM}$ and the total organic $\mathrm{C}$ ratio were considered, only the negative control was lower due to the absence of fresh organic input with high coarse mineral (siliceous pebbles) and sand contents. Post-restoration vegetation establishment was much slower in the negative control than other treatments (Bulot et al. 2014). In 2013, the high $\mathrm{C}: \mathrm{N}$ ratio of POM measured in the reference steppe could be explained both by greater inputs of organic matter and by slow degradation of POM mainly because of the more extensive belowground biomass (herbaceous perennial plant roots) in the reference steppe than in the other treatments as revealed by the soil profiles. The lower $\mathrm{C}: \mathrm{N}$ ratio of POM in the treatment "subsoil" indicates higher quality litter inputs in the past. This was due to the nature of the subsoil layer which contains old, inherited organic matter associated with the mineral fraction of the soil (AFES 2009). The soil profile description of this treatment also shows the presence of only a few fine roots of annual plants, suggesting that there was very limited input of 
fresh organic matter after its transfer. High variation in the $\mathrm{C}: \mathrm{N}$ ratio of POM, measured in the transferred altered bedrock in 2012 and between 2012 and 2013, was certainly due to the fact that the samples were taken close to a small patch of annual vegetation instead of from the bare soil characteristic of most of soil surface of this treatment.

Similar potential carbon mineralization rates were obtained in the soil transfer treatments (except for the negative control) and in the reference steppe. Thus, the decrease in POM content measured between 2012 and 2013 in the treatment "topsoil" could not be explained by higher $\mathrm{C}$ mineralization. Because new inputs of organic matter from perennial plants were lower in this horizon than in the reference steppe, the original stock of organic matter was likely mineralized and not renewed. In the treatment "subsoil," the biodegradation of organic carbon and mineralization of nitrogen reduced the old organic matter content whereas, in the transferred altered bedrock, new inputs of fresh organic matter from annual plants enriched this poor treatment in organic matter. Thus, carbon mineralization varied greatly depending on whether there was rapid colonization of new organic matter by microorganisms and thus rapid mineralization or no mineralization in bare soil areas without inputs of fresh organic matter.

Nitrogen mineralization measured in 2013 indicated high rates of nitrification. This mineralization was similar between the treatments "subsoil," "topsoil," and "step." This means that microorganisms were able to find their energy resources even in the old organic matter which characterized the subsoil layer. In the negative control, microbial activity immobilized the little available $\mathrm{N}$, making $\mathrm{N}$ the limiting factor. Two to three years after the soil transfer, net $\mathrm{N}$ mineralization tended to decrease, most likely due to the associated decrease in POM.

Microbial microrespirometric measurements suggested a positive gradient of microbial biomass and $\mathrm{BR}$ and a negative gradient of metabolic quotient $\left(\mathrm{qCO}_{2}\right)$ among the restoration treatments with increasing vertical organization to the steppe soil. The higher $\mathrm{qCO}_{2}$ values, especially in the negative control, can be explained in part by low microbial biomass and presence of a "younger microbial community" with higher energy needs, as demonstrated by the trend to more mineralize the nitrogen to cope with the new soil conditions created after soil transfer and the ensuing surface exposure of the altered bedrock (Anderson \& Domsch 1990). In addition, the microbial communities' efficiency to catabolize malic acid in the reference steppe, and to a lesser extent in the treatment "topsoil," may be explained by feedback between plants and microbial edaphic environment, through root exudates and their direct input of organic matter. As floristic surveys have shown (Bulot et al. 2014), some plant species were present both on the treatment "topsoil" and on the reference steppe but to a far lesser extent on the treatment "subsoil" and on the negative control. Some plants were from families known to contain C4 species (ex: Poaceae), which can produce malic acid, particularly under conditions of waterstress (Du et al. 2012). Other plants produce organic acids, including malic acid, under conditions of nutrient limitation (Ryan et al. 2001). It is possible that the abundance of plants with the potential to produce and excrete malic acid favored development of soil microbial communities in the reference steppe and treatment "topsoil" that catabolize malic acid.

Our hypothesis was that the reconstitution of all pedological horizons would improve soil recovery in the short term concerning topsoil functioning (microbial biomass and activity, nutrient dynamics, and organic matter fractions) and profile morphology. Our results supported this hypothesis because the soil functions of the treatment "topsoil" closely resembled those of the reference steppe even after 3 years, and that any remaining differences were likely due to differences in the soil heterogeneity and in plant community composition and dynamics, which may arise from the grazing in the surrounding undisturbed steppe (Bulot et al. 2014; Jaunatre et al. 2014). Other studies have already demonstrated that, in some dry ecosystems, raw soil substrate gave successful restoration results (Tischew \& Kirmer 2007; Eichberg et al. 2010) and that vertical organization of the soil layers did not seem important. However, soil transfer may also result in altered biological activity, profile morphology, and organic matter content compared with the reference system. Because the physicochemical, microbial parameters', and soil profiles' morphology respond differently after restoration in the short term, these different soil parameters should be studied now in the long term.

In conclusion, soil transfer can be used as a restoration technique because it is a method which can have encouraging results concerning the short-term plant recovery (Kiehl et al. 2010; Bulot et al. 2014; Jaunatre et al. 2014), and which allows the maintenance of a low fertility of removed and transferred soil as revealed by the results of our study. Nevertheless, the transfer of large quantities of soil requires the use of civil engineering methods (use of worksite earth moving equipment, transport trucks, etc.), which involves hydrocarbon consumption, greenhouse gas emissions $\left(\mathrm{CO}_{2}, \mathrm{NO}_{\mathrm{x}}\right.$, etc.), soil compaction, and alteration during transportation. Soil transfer must then be employed in last resort for restoration of extremely degraded ecosystems, as in the case for reclamation of mined lands (DePuit 1984; Helm \& Carling 1993; Sheoran et al. 2010), and it should be also limited to particular cases where the destruction of the soil of the donor site is inevitable and independently planned (Bullock 1998; Bruelheide \& Flintrop 2000; McLean 2003; Vécrin \& Muller 2003).

\section{LITERATURE CITED}

Anderson JPE, Domsch KH (1978) A physiological method for the quantitative measurement of microbial biomass in soils. Soil Biology and Biochemistry 10:215-221

Anderson TH, Domsch KH (1990) Application of eco-physiological quotients ( $\mathrm{qCO} 2$ and $\mathrm{qD}$ ) on microbial biomasses from soils of different cropping histories. Soil Biology and Biochemistry 22:251-255

Association Française pour l'Etude du Sol (AFES), Baize D, Girard MC (2009) Référentiel pédologique 2008. Éditions Quæ, Versailles, France

Baize D (2000) Guide des analyses pédologiques. $2^{\text {nd }}$ edition. INRA, Paris, France

Baize D, Jabiol B (2011) Guide pour la description des sols. Editions Quae, Versailles, France

Bell CW, Acosta-Martinez V, McIntyre NE, Cox S, Tissue DT, Zak JC (2009) Linking microbial community structure and function to seasonal 
differences in soil moisture and temperature in a Chihuahuan desert grassland. Microbial Ecology 58:827-842

Benjamini Y, Hochberg Y (1995) Controlling the false discovery rate: a practical and powerful approach to multiple testing. Journal of the Royal Statistical Society, Series B 57:289-300

Bérard A, Bouchet T, Sévenier G, Pablo AL, Gros R (2011) Resilience of soil microbial communities impacted by severe drought and high temperature in the context of Mediterranean heat waves. European Journal of Soil Biology 47:333-342

Bourrelly M, Borel L, Devaux JP, Louis-Palluel J, Archiloque A (1983) Dynamique annuelle et production primaire nette de l'écosystème steppique de Crau (Bouches du Rhône). Biologie et Ecologie Méditerranéenne 10:55-82

Bruelheide H, Flintrop T (2000) Evaluating the transplantation of a meadow in the Harz Mountains, Germany. Biological Conservation 92:109-120

Bullock JM (1998) Community translocation in Britain: setting objectives and measuring consequences. Biological Conservation 84:199-214

Bulot A, Provost E, Dutoit T (2014) A comparison of different soil transfer strategies for restoring a Mediterranean steppe after a pipeline leak (La Crau plain, South-Eastern France). Ecological Engineering 71:690-702

Cambardella CA, Elliott ET (1992) Particulate soil organic-matter changes across a grassland cultivation sequence. Soil Science Society of America Journal $56: 777-783$

Campbell CD, Chapman SJ, Cameron CM, Davidson MS, Potts JM (2003) A rapid microtiter plate method to measure carbon dioxide evolved from carbon substrate amendments so as to determine the physiological profiles of soil microbial communities by using whole soil. Applied and Environmental Microbiology 69:3593-3599

Carter MR, Angers DA, Gregorich EG, Bolinder MA (2003) Characterizing organic matter retention for surface soils in eastern Canada using density and particle size fractions. Canadian Journal of Soil Science 83:11-23

Chapman SJ, Campbell CD, Artz RRE (2007) Assessing CLPPs using MicroResp ${ }^{\mathrm{TM}}$.A comparison with biolog and multi-SIR. Journal of Soils and Sediments 7:406-410

Chessel D, Dufour AB, Thioulouse J (2004) The ade4 Package-I-One-table methods. R News 4:5-10

Clewell AF, Aronson J (2013) Ecological restoration: principles, values, and structure of an emerging profession. Island Press, Washington, DC, United States

Coiffait-Gombault C, Buisson E, Dutoit T (2012) Are old Mediterranean grasslands resilient to human disturbances? Acta Oecologica 43:86-94

Curry JP (2004) Factors affecting the abundance of earthworms in soils. Earthworm Ecology 9:113

DeGryze S, Six J, Paustian K, Morris SJ, Paul EA, Merckx R (2004) Soil organic carbon pool changes following land-use conversions. Global Change Biology 10:1120-1132

DePuit EJ (1984) Potential topsoiling strategies for enhancement of vegetation diversity on mined lands. Minerals and the Environment 6:115-120

Devaux JP, Archiloque A, Borel L, Bourrely M, Louis-Palluel J (1983) Notice de la carte phyto-écologique de la Crau (Bouches-du-Rhône). Biologie et écologie méditerranéenne 10:5-54

Dray S, Dufour AB (2007) The ade4 package: implementing the duality diagram for ecologists. Journal of Statistical Software 22:1-20

Du H, Wang Z, Yu W, Huang B (2012) Metabolic responses of hybrid bermudagrass to short-term and long-term drought stress. Journal of the American Society for Horticultural Science 137:411-420

Edwards CA (2002) Assessing the effects of environmental pollutants on soil organisms, communities, processes and ecosystems. European Journal of Soil Biology 38:225-231

Eichberg C, Storm C, Stroh M, Schwabe A (2010) Is the combination of topsoil replacement and inoculation with plant material an effective tool for the restoration of threatened sandy grassland? Applied Vegetation Science $13: 425-438$

Feller C (1979) Une méthode de fractionnement granulométrique de la matière organique des sols. Cahiers ORSTOM série Pédologie 17:339-346
Fontaine S, Mariotti A, Abbadie L (2003) The priming effect of organic matter: a question of microbial competition? Soil Biology and Biochemistry $35: 837-843$

Fox J, Weisberg S (2011) An R companion to applied regression. $2^{\text {nd }}$ edition. Sage Publications, London, England

Franzluebbers AJ (2002) Soil organic matter stratification ratio as an indicator of soil quality. Soil and Tillage Research 66:95-106

Hart SC, Stark JM, Davidson EA, Firestone MK (1994) Nitrogen mineralization, immobilization, and nitrification. Pages 985-1017. In: Page AL, Miller RH, Keeney DR (eds) Methods of soil analysis, Part II: Microbiological and biochemical properties. Soil Science Society of America, Madison, Wisconsin

Haynes RJ (2000) Labile organic matter as an indicator of organic matter quality in arable and pastoral soils in New Zealand. Soil Biology and Biochemistry 32:211-219

Helm DJ, Carling DE (1993) Use of soil transfer for reforestation on abandoned mined lands in Alaska. Mycorrhiza 3:97-106

Heneghan L, Miller SP, Baer S, Callaham MA, Montgomery J, Pavao-Zuckerman M, Rhoades CC, Richardson S (2008) Integrating soil ecological knowledge into restoration management. Restoration Ecology 16:608-617

Henry F, Talon B, Dutoit T (2010) The age and the history of the French Mediterranean steppe revisited by soil wood charcoal analysis. The Holocene 20:25-34

Janssens F, Peeters A, Tallowin JRB, Bakker JP, Bekker RM, Fillat F, Oomes MJM (1998) Relationship between soil chemical factors and grassland diversity. Plant and soil 202: 69-78

Jaunatre R, Buisson E, Dutoit T (2014) Can ecological engineering restore Mediterranean rangeland after intensive cultivation? A large-scale experiment in southern France. Ecological Engineering 64:202-212

Johnson DB, Williamson JC, Bailey AJ (1991) Microbiology of soils at opencast coal sites. I. Short-and long-term transformations in stockpiled soils. Journal of Soil Science 42:1-8

Kiehl K, Kirmer A, Donath TW, Rasran L, Hölzel N (2010) Species introduction in restoration projects-Evaluation of different techniques for the establishment of semi-natural grasslands in Central and Northwestern Europe. Basic and Applied Ecology 11:285-299

Krull ES, Baldock JA, Skjemstad JO (2003) Importance of mechanisms and processes of the stabilisation of soil organic matter for modelling carbon turnover. Functional Plant Biology 30:207-222

Kutílek M, Jendele L, Lichner L, Kodešová R, Tesař M (2008) The structural porosity in soil hydraulic functions-a review. Soil and Water Research 3:S7-S20

McLean IFG (2003) A habitats translocation policy of Britain. Joint Nature Conservation Committee, Peterborough, Ontario, Canada

Metson AJ (1957) Methods of chemical analysis for soil survey samples. Soil Science 83:245

Molliex S, Siame LL, Bourlès DL, Belleir O, Braucher R, Clauzon R (2013) Quaternary evolution of a large alluvial fan in a periglacial setting (Crau Plain, SE France) constrained by terrestrial cosmogenic nuclide $\left({ }^{10} \mathrm{Be}\right)$. Geomorphology 195:45-52

NF X31-516 French standard (2007) Qualité du sol - Fractionnement granulométrique des matières organiques particulaires du sol dans l'eau. Association Française de Normalisation (AFNOR), Saint-Denis La Plaine, Paris

Nwaishi F, Petrone RM, Price JS, Ketcheson SJ, Slawson R, Andersen R (2015) Impact of donor-peat management practices on the functional characteristics of a constructed fen. Ecological Engineering 81:471-480

Olsen SR, Cole CV, Watanabe FSD, Dean LA (1954) Estimation of available phosphorus in soils by extraction with sodium bicarbonate. Department of Agriculture, Washington, DC, United States, circular 939

Parr JF, Papendick RI (1997) Soil quality: Relationships and strategies for sustainable dryland farming systems. Annals of Arid Zone 36:181-191

Pfannenstiel VR, Wendt GW (1984) Enhancing shrub establishment by utilizing direct haul topsoil on mine spoils in western Colorado. In: Proc., Symposium on the Reclamation of Lands Disturbed by Surface Mining: A Cornerstone for Communication and Understanding, U.S. Forest Service, Owensbro, Kentucky, 1-14 
Radford BJ, Wilson-Rummenie AC, Simpson GB, Bell KL, Ferguson MA (2001) Compacted soil affects soil macrofauna populations in a semi-arid environment in central Queensland. Soil Biology and Biochemistry 33:1869-1872

Renault P, Ben-Sassi M, Berard A (2013) Improving the MicroResp ${ }^{\mathrm{TM}}$ substrate-induced respiration method by a more complete description of $\mathrm{CO}_{2}$ behavior in closed incubation wells. Geoderma 207:82-91

Robertson GP, Wedin D, Groffman PM, Blair JM, Holland EA, Nadelhoffer KJ, Harris D (1999) Soil carbon and nitrogen availability: nitrogen mineralization, nitrification and soil respiration. Pages 258-271. In: Robertson GP, Coleman DC, Bledsoe CS, Sollins P (eds) Standard soil methods for long-term ecological research. Oxford University Press, Oxford, U.K.

Römermann C, Tackenberg O, Poschold P (2005) How to predict attachment potential of seeds to sheep and cattle coat from simple morphological seed traits. Oikos 110:219-230

Ryan PR, Delhaize E, Jones DL (2001) Function and mechanism of organic anion exudation from plant roots. Annual Review of Plant Biology 52: $527-560$

Schils R, Kuikman P, Liski J, Oijen MV, Smith P, Webb J, et al. (2008) Review of existing information on the interrelations between soil and climate change. (ClimSoil) Final report, European Commission, Brussels, Belgium

Sheoran V, Sheoran AS, Poonia P (2010) Soil reclamation of abandoned mine land by revegetation: a review. International Journal of Soil, Sediment and Water 3:13

Stengel P, Bruckler L, Balesdent J (2009) Le sol. Editions Quae, INRA, Versailles, France

Tischew S, Kirmer A (2007) Implementation of basic studies in the ecological restoration of surface-mined land. Restoration Ecology 15:321-325
Trueman I, Mitchell D, Besenyei L (2007) The effects of turf translocation and other environmental variables on the vegetation of a large species-rich mesotrophic grassland. Ecological Engineering 31:79-91

Trumbore S (2009) Radiocarbon and soil carbon dynamics. Annual Review of Earth and Planetary Sciences 37:47-66

Unger PW, Kaspar TC (1994) Soil compaction and root growth: a review. Agronomy Journal 86:759-766

Van-Camp L, Bujarrabal B, Gentile AR, Jones RJA, Montanarella L, Olazabal C, Selvaradjou SK (2004) Reports of the Technical Working Groups Established under the Thematic Strategy for Soil Protection. EUR 21319 EN/1, Office for Official Publications of the European Communities, Luxembourg

Vécrin MP, Muller S (2003) Top-soil translocation as a technique in the recreation of species-rich meadows. Applied Vegetation Science 6:271-278

Whalley WR, Dumitru E, Dexter AR (1995) Biological effects of soil compaction. Soil and Tillage Research 35:53-68

WRB (2006) World reference base for soil resources, a framework for international classification, correlation and communication. World soil resources reports. Food and Agriculture Organization of the United Nations, Rome 128

Xu Z, Zhou G, Wang Y (2007) Combined effects of elevated CO2 and soil drought on carbon and nitrogen allocation of the desert shrub Caragana intermedia. Plant and Soil 30:87-97

Zhou L, Huang J, Lü F, Han X (2009) Effects of prescribed burning and seasonal and interannual climate variation on nitrogen mineralization in a typical steppe in Inner Mongolia. Soil Biology and Biochemistry $41: 796-803$ 